IJPSR (2011), Vol. 2, Issue 1

(Research Article)
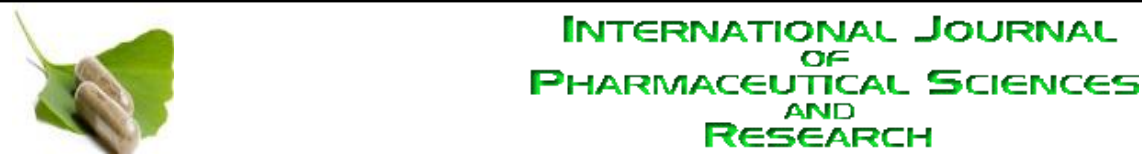

Received on 04 August, 2010; received in revised form 10 November, 2010; accepted 26 December, 2010

\title{
ESTIMATION OF LORNOXICAM IN TABLET DOSAGE FORM BY UV SPECTROPHOTOMETRIC METHOD
}

Bhupendra Singh*, Geetanjali Saini, Devendra N Naath Sharma, Saumendu Deb Roy and Nishant Gautam

Abhilashi College of Pharmacy, Tanda, Ner Chowk, Mandi, H.P., India

\begin{tabular}{|c|c|}
\hline & ABSTRACT \\
\hline $\begin{array}{l}\text { Keywords: } \\
\text { Lornoxicam, } \\
\text { UV-spectrophotometry, } \\
\text { Absorbance, } \\
\text { Validation }\end{array}$ & $\begin{array}{l}\text { Lornoxicam (chlortenoxicam) is a non steroidal anti- } \\
\text { inflammatory drug (NSAID) of the oxicam class with } \\
\text { analgesic, anti-inflammatory and antipyretic properties. It is } \\
\text { available in oral and parental dosage formulation. } \\
\text { Lornoxicam is a Yellow or slightly yellow powder. It is slightly }\end{array}$ \\
\hline $\begin{array}{l}\text { Correspondence to Author: } \\
\text { Bhupendra Singh } \\
\text { Abhilashi College of Pharmacy, } \\
\text { Tanda, Ner Chowk, Mandi, H.P., India }\end{array}$ & $\begin{array}{l}\text { soluble in water, soluble in hydrochloric acid, slightly soluble } \\
\text { in methanol. A simple spectrophotometric method was } \\
\text { developed for the determination of lornoxicam in } \\
\text { pharmaceutical tablet dosage form. Lornoxicam exhibiting } \lambda \\
\text { max at } 380 \mathrm{~nm} \text { in mobile phase (phosphate buffer: } \\
\text { methanol) in ratio of } 50: 50 \text { and obeyed linearity in the } \\
\text { concentration range of } 1-20 \mathrm{mcg} \text {. The proposed method was } \\
\text { statistically validated. }\end{array}$ \\
\hline
\end{tabular}


INTRODUCTION: The scope of developing and validating analytical method is to ensure a suitable method for a particular analyte more specific, accurate and precise the main objective for that is to improve the condition and parameter, which should be followed in the development and validation ${ }^{2}$. Lornoxicam (chlortenoxicam) is a non steroidal antiinflammatory drug (NSAID) of the oxicam class with analgesic, anti-inflammatory, and antipyretic properties $^{1,4}$.

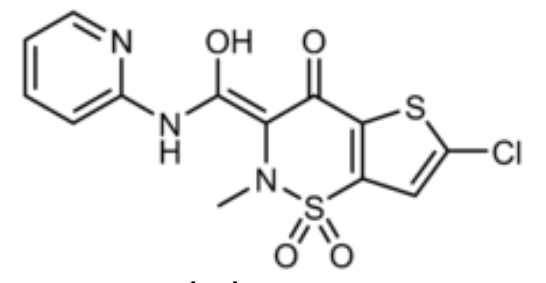

FIG.1: LORNOXICAM: (3E) - 6- CHLORO- 3- [HYDROXY (PYRIDIN- 2- YLAMINO) METHYLENE] - 2- METHYL-2, 3DIHYDRO- 4H- THIENO [2, 3-E] [1, 2] THIAZIN- 4- ONE 1, 1DIOXIDE

Tablet formulation containing $4 \mathrm{mg}$ and $8 \mathrm{mg}$ lornoxicam in film-coated and dispersible form are available in the market. Literature survey revealed that various analytical methods such as TLC, HPLC, liquid chromatography, polarographic method, LC-ESI-MS (liquid chromatographyElectrospray ionization- tandem- mass spectrometric) are used for estimation of lornoxicam ${ }^{4,5}$.

No UV-Spectrophotometric method has been reported for estimation of lornoxicam in tablet dosage form. Hence, an attempt has been made to develop new spectrophotometry method for its estimation in pharmaceutical tablet dosage form with good accuracy, simplicity, and precision. In UV-Spectrophotometric method UV spectrum is set in $380 \mathrm{~nm}$ and blank is placed in the cuvettes, after setting zero transmittance the sample is placed in another cuvette for measuring the absorbance the sample.

EXPERIMENTAL: Absorbance measurements were made on Electronic India (EI) Spectrophotometer. Shimadzu BL-220H balance was used for weighing the sample. Commercially available tablets of the lornoxicam were procured from the local market and estimated.

\begin{tabular}{ccc}
\multicolumn{2}{c}{ Apparatus/Instruments: } \\
\hline Name & Model & Manufacturer/supplier \\
\hline UV- VIS & El- 371 & Electronic India \\
Spectrophotometer & & Shimadzu \\
Balance & BL- $220 \mathrm{H}$ & Popular, India \\
Water purification unit & - & \\
\hline
\end{tabular}

Chemicals and Reagents:

\begin{tabular}{cc}
\hline Solvents and Reagents & Manufacturer \\
\hline Sodium dihydrogen phosphate & Merck \\
anhydrous & Nice \\
Sodium hydroxide & (LR) \\
Methanol & SDFCL \\
Water & Distilled water \\
Lornoxicam Standard & Ranbaxy laboratories. Ltd. \\
\end{tabular}

\section{METHOD:}

Scanning and determination of maximum wavelength (fig. 2):

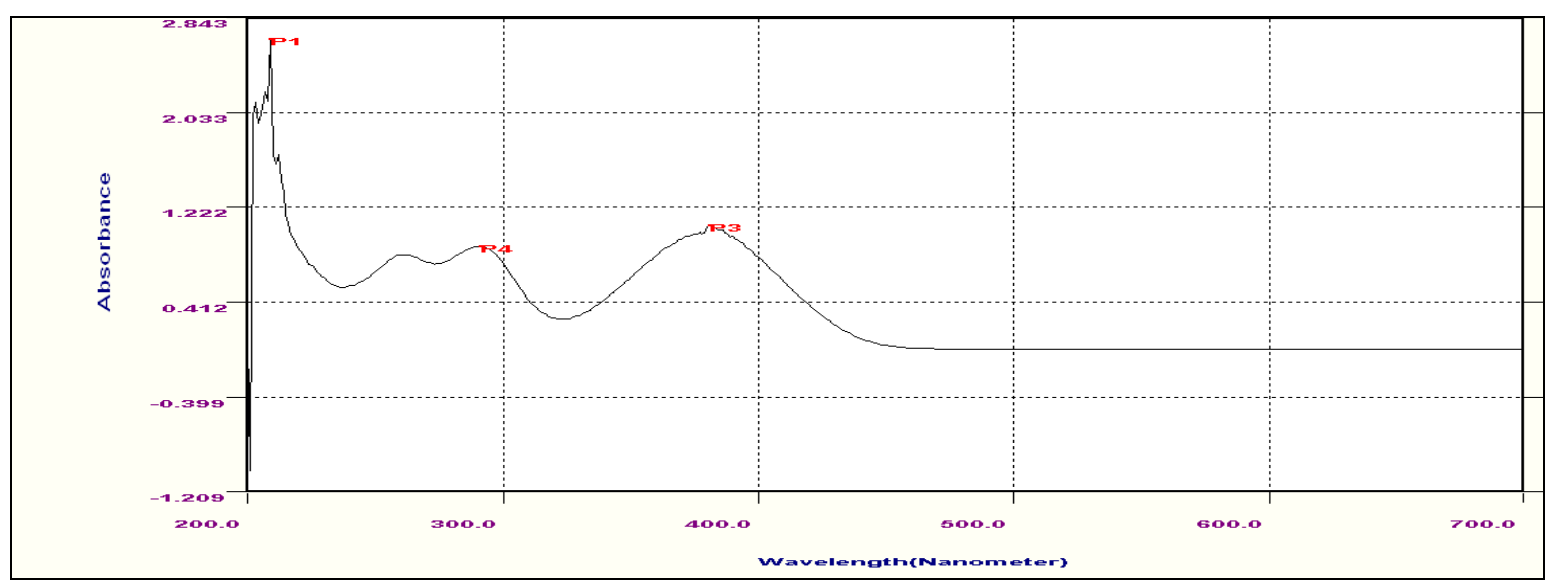

FIG 2: DETERMINATION OF MAXIMUM WAVELENGTH OF LORNOXICAM 
Preparation of $0.2 \mathrm{M}$ Phosphate buffer solution: $17.8 \mathrm{gm}$ of sodium dihydrogen phosphate dissolved in $250 \mathrm{ml}$ of distilled water and volume made up to $500 \mathrm{ml}$ by distilled water in 500 volumetric flasks. To $250 \mathrm{ml}$ of $0.2 \mathrm{M}$ sodium dihydrogen phosphate solution freshly prepared $0.2 \mathrm{M} \mathrm{NaOH}(58 \mathrm{ml})$ is added to it and volume made up to $500 \mathrm{ml}$ by distilled water and $\mathrm{pH}$ of buffer is 6.5 .

Preparation of mobile phase $(100 \mathrm{ml}):$ mix $50 \mathrm{ml}$ of $0.2 \mathrm{M}$ Phosphate buffer and $50 \mathrm{ml}$ of Methanol to made mobile phase of Phosphate buffer: methanol in ratio 50:50.

Preparation of standard stock solution: Standard stock solution was prepared by dissolving $50 \mathrm{mg}$ of lornoxicam in $50 \mathrm{ml}$ of mobile phase to get concentration of $1 \mathrm{mg} / \mathrm{ml}$.

Preparation of working standard solution and construction of calibration curve: The prepared stock solution was further diluted with mobile phase to get working standard solution of 1, 2, 4, 6,8 , and $10 \mathrm{mcg}$ of lornoxicam to construct Beer's law plot for the pure drug, the absorbance was measured at $\lambda \max$ at $380 \mathrm{~nm}$, against mobile phase as blank. The standard graph was plotted by taking concentration of drug on $\mathrm{X}$-axis and absorbance on $\mathrm{Y}$-axis in the concentration range of $1-20 \mathrm{mcg}$.

Preparation of sample stock solution and working sample solution: Ten tablets were accurately weighed and average was calculated. The tablet were then crushed to obtain fine powder equivalent to about $8 \mathrm{mg}$ of lornoxicam was transferred to $100 \mathrm{ml}$ volumetric flask, added mobile phase and shaken for a while. The volume was made up to the mark with mobile phase and required dilutions were made from the sample stock solution.

Validation $^{3}$ :

Assay: The assay of the proposed method was ascertained by performing assay of the standard drug with reference to the sample drug and finding out the absorbance. From the absorbance percentage purity was calculated. The readings are shown in table 1.

TABLE 1: ASSAY OF LORNOXICAM TABLET

\begin{tabular}{cccc}
\hline Lorsaid*8 & $\begin{array}{c}\text { Claim of tablet } \\
\text { (mg/tablet) }\end{array}$ & $\begin{array}{c}\text { Drug found } \\
\text { (mg/tablet) }\end{array}$ & \% Purity \\
\cline { 2 - 4 } & 8 & 8.056 & 100.71 \\
\hline
\end{tabular}

SPECIFICITY: The specificity of the proposed method was ascertained by performing the placebo study. The placebo was obtained from the Primal healthcare equivalent to one tablet and the percent interference was carried out from these data's ${ }^{2,3}$ (table 2).

TABLE 2: SPECIFICITY READING

\begin{tabular}{ccc}
\hline $\begin{array}{c}\text { Placebo } \\
\text { absorbance }\end{array}$ & $\begin{array}{c}\text { Standard } \\
\text { absorbance }\end{array}$ & Specificity range\% \\
\hline 0.030 & 0.422 & 3.67 \\
\hline
\end{tabular}

Linearity: To establish linearity of the proposed methods, six separate series of solutions of lornoxicam (1-20 $\mathrm{mcg})$ in mobile phase (phosphate buffer: methanol, 50:50) were prepared from the stock solutions and analyzed. Least square regression analysis was performed on the obtained data. Linearity data are shown in table $3 \& \mathbf{4}$ as follows:

TABLE 3: LINEARITY TABLE OF LORNOXICAM IN WORKING STANDARD

\begin{tabular}{cc}
\hline Concentration $(\mathrm{mcg})$ & Absorbance \\
\hline 0 & 0 \\
1 & 0.037 \\
2 & 0.116 \\
4 & 0.189 \\
6 & 0.284 \\
8 & 0.369 \\
10 & 0.451 \\
12 & 0.531 \\
14 & 0.613 \\
16 & 0.686 \\
18 & 0.771 \\
20 & 0.819 \\
\hline
\end{tabular}




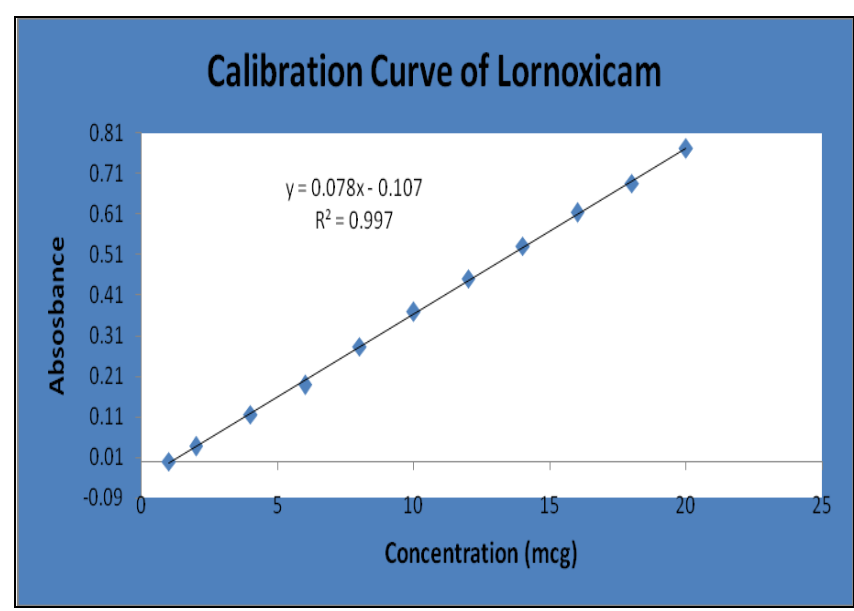

FIG. 3: LINEARITY CURVE OF LORNOXICAM IN WORKING STANDARD
TABLE 4: LINEARITY CURVE DATA

\begin{tabular}{cc} 
Beer's law limit $(\mathbf{m c g})$ & $1-20$ \\
Correlation coefficient $\left(\mathbf{R}^{2}\right)$ & 0.997 \\
Regression equation $\left(\mathrm{y}^{*}\right)$ & $\mathrm{Y}=0.078 \mathrm{x}-0.107$ \\
Slope $(\mathrm{m})$ & 0.078 \\
Y-Intercept(c) & 0.0107 \\
\hline
\end{tabular}

Accuracy: To determine the accuracy of the proposed method, recovery studies were carried out by adding different amounts (80\%, 100\%, and $120 \%$ ) of standard bulk sample of lornoxicam within the linearity range were taken and added to the pre-analyzed formulation of concentration $10 \mathrm{mcg}$ and percentage recovery values are calculated ${ }^{2,3}$ (Table 5 \& 6).

TABLE 5: ACCURACY \% RECOVERY READING

\begin{tabular}{|c|c|c|c|c|}
\hline \multirow{2}{*}{ Sample ID (\%) } & \multicolumn{2}{|c|}{ Concentration (mcg) (mean) } & \multirow{2}{*}{$\begin{array}{c}\text { \%Recovery of pure } \\
\text { drug(mean) }\end{array}$} & \multirow{2}{*}{ Statistical analysis } \\
\hline & Pure drug & formulation & & \\
\hline \multirow{2}{*}{$80^{*}$} & \multirow{2}{*}{6.45} & \multirow[t]{2}{*}{8.0} & \multirow{2}{*}{124.03} & $S D=0.000577$ \\
\hline & & & & $\% \mathrm{RSD}=0.00047$ \\
\hline \multirow{2}{*}{$100^{*}$} & \multirow{2}{*}{8.0} & \multirow[t]{2}{*}{8.0} & \multirow{2}{*}{112.10} & $S D=0.001$ \\
\hline & & & & $\% \mathrm{RSD}=0.00089$ \\
\hline \multirow{2}{*}{$120^{*}$} & \multirow{2}{*}{9.6} & \multirow[t]{2}{*}{8.0} & \multirow{2}{*}{95.01} & $S D=0.001528$ \\
\hline & & & & $\% \mathrm{RSD}=0.0016$ \\
\hline
\end{tabular}

${ }^{*} \mathrm{n}=6$ replicates; $\%$ Recovery $=$ Amount recovered /Amount added $\times 100$

TABLE 6: ACCURACY STUDIES

\begin{tabular}{cc}
\hline Concentration (\%) & Absorbance (mean) \\
\hline 80 & 0.353 \\
100 & 0.486 \\
120 & 0.593 \\
Correlation coefficient $\left(\mathrm{R}^{2}\right)$ & 0.996 \\
Regression equation $\left(\mathrm{V}^{*}\right)$ & $\mathrm{Y}=0.12 \mathrm{x}+0.237$ \\
Slope $(\mathrm{m})$ & 0.12 \\
Y-Intercept $(\mathrm{c})$ & 0.237 \\
\hline
\end{tabular}

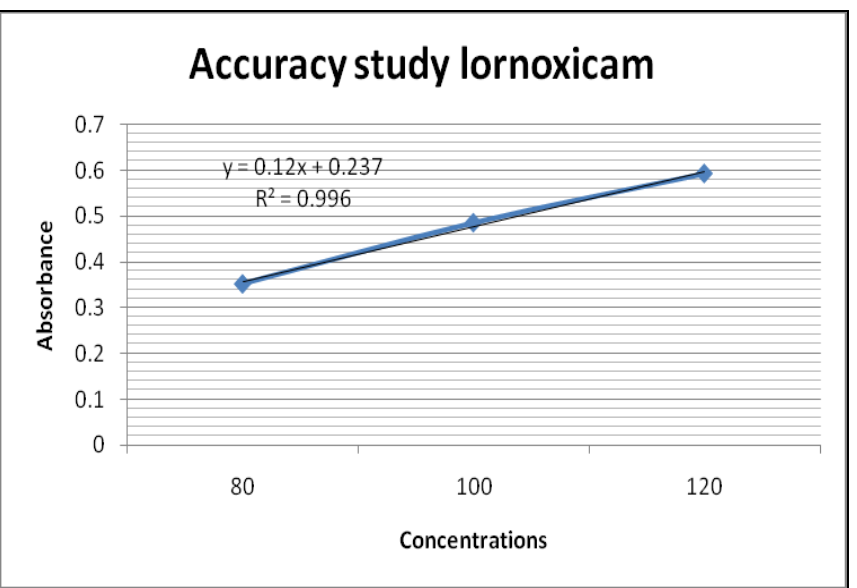

FIG. 4: ACCURACY CURVE OF LORNOXICAM IN REFERENCE STANDARD
Precision: The precision of the proposed method was ascertained by determination of six replicates of same concentration of sample and standard for method precision and system precision.

System precision: The system precision of the proposed method was ascertained by determination of six replicates of same concentration of standard drug within the Beer's range and finding out the absorbance. The mean absorbance, standard deviation, and \%RSD were calculated $^{2,3}$ (Table 7).

TABLE 7: SYSTEM PRECISION READING

\begin{tabular}{ccc}
\hline $\begin{array}{c}\text { Concentration } \\
(\mathbf{m c g}) \text { mean }\end{array}$ & Absorbance (mean) & $\begin{array}{c}\text { Statistical } \\
\text { analysis }\end{array}$ \\
\hline \multirow{2}{*}{$10^{*}$} & 0.411 & $\mathrm{SD}=0.008$ \\
& & $\% \mathrm{RSD}=1.9$ \\
\hline
\end{tabular}

\footnotetext{
$* n=6$ replicates
}

Method precision: The method precision of the proposed method was ascertained by determination of six replicates of same 
concentration of sample drug within the Beer's range and finding out the absorbance. The absorbance, assay of drug, standard deviation, and \%RSD were calculated (Table 8 \& 9).

\section{TABLE 8: METHOD PRECISION READING}

\begin{tabular}{ccccc}
\hline $\begin{array}{c}\text { Conc. } \\
\text { (mcg) } \\
\text { mean }\end{array}$ & $\begin{array}{c}\text { Absorbance } \\
\text { (mean) }\end{array}$ & $\begin{array}{c}\text { Assay } \\
\text { (mean) }\end{array}$ & $\begin{array}{c}\text { \%Purity } \\
\text { (mean) }\end{array}$ & $\begin{array}{c}\text { Statistical } \\
\text { analysis }\end{array}$ \\
\hline $10^{*}$ & 0.415 & 7.848 & 98.06 & $\begin{array}{c}\text { \% } \\
\text { \%SD }=0.0416 \\
3007\end{array}$ \\
\hline
\end{tabular}

$* n=6$ replicates

TABLE 9: SUMMARY OF VALIDATION PARAMETER

\begin{tabular}{cc}
\hline Validation parameter & Observation \\
\hline Specificity & 3.67 \\
$\%$ interference & $1-10$ \\
Linearity $(\mu \mathrm{g} / \mathrm{ml})$ & \\
Precision (RSD) & \\
Repeatability & 1.9 \\
system precision $(\mathrm{n}=6)$ & 0.53007 \\
method precision $(\mathrm{n}=6)$ & \\
Accuracy & $95-124$ \\
\hline
\end{tabular}

\section{RESULT AND DISCUSION: From these} characteristics of the proposed method, it was found that lornoxicam follow linearity with in the concentration range of $1-20 \mathrm{mcg}$. The table 8 and 9 indicated that the \%RSD is less than 2 , which shows that the system and method has good reproducibility. The result shown in accuracy table (5) and (6), it was found that the percentage recovery values of pure drug from the analyzed solution of formulation were in between 95.01 to 124 which indicates that the proposed method is accurate and also reveals that the commonly use excipients and additives in the pharmaceutical formulation were not interfering in the proposed method.

CONCLUSION: The proposed method was simple and reliable with good precision, accuracy, linearity and ruggedness. The proposed method is specific while estimating the commercial formulations without interference of the excipients and other additives. Hence, this method can be used for the routine determination of lornoxicam in pure and pharmaceutical formulation.

ACKNOWLEDGEMENT: The Authors are sincerely thankful to Ranbaxy Pvt. Ltd., Gurgaon, for providing the gift sample of lornoxicam and also very much thankful to Mr. R. K. Abhilashi, Chairman, Abhilashi College of Pharmacy, for providing with the Facilities to carry out this work and also for his continuous support and encouragement.

\section{REFERENCES:}

1. Wikipedia, the Free Encyclopedia.

2. Nash R.A.and Wachter. A.; Pharmaceutical Process Validation; Published by Dekker incorporated, Marcel; (2003) 507-521.

3. International Conference on Harmonization of technical requirement for the registration of pharmaceutical for human use. Validation of analytical procedures: methodology.ICH- Q2B, Geneva (1996)

4. Patil Kiran R., Rane Vipul P., Jaiprakash N. Sangshetti and Shinde Devanand B., Stability-Indicating LC Method for Analysis of Lornoxicam in the Dosage Form, Journal of chromatographia, May, (2009), 9-10

5. Brahim Cetin, Nisa Kocak, Sule Aycan; polarographic determination of lornoxicam in pharmaceutical formulations; C.B.U. Journal of Science, (2009) $11-18$.

6. Young Hoon Kim, Hye Young Ji, Liquid chromatographyElectrospray lionization tandem mass spectrometric determination of lornoxicam in human plasma, Archives of Pharmacal Research, July 2007 Vol.30, 905-910

7. Hanna Hopkała, Arkadiusz Pomykalski; "TLC analysis of inhibitors of cyclooxygenase and videodensitometric determination of meloxicam, lornoxicam and tiaprofenic acid" Journal of Planar Chromatography - Modern TLC; (2003), 107-111

A. Savaşer, A. Karataş, Y. Özkan; "Validated LC Determination of the Piroxicam-ß-Cyclodextrin Inclusion Complex in Tablets and in Human Plasma" Journal of chromatographia, October (2003) 555-560.

8. Puthli S. P. and Vavia P. R, "Stability indicating HPTLC determination of piroxicam" Journal of Pharmaceutical and Biomedical Analysis, May (2000) 673-677.

9. D. de Jager, H. Ellis, H. K. L. Hundt, K. J. Swart, "Highperformance liquid chromatographic determination with amperometric detection of piroxicam in human plasma and tissues" Journal of Chromatography B: Biomedical Sciences and Applications June (1999), 183-189 